\title{
Gastrointestinal mast cells in health, and in coeliac disease and other conditions
}

\author{
L DOLLBERG, M GUREVITZ, AND S FREIER \\ Department of Paediatrics, and Institute of Pathology, Shaare Zedek Medical Centre, Jerusalem
}

SUMMARY Intestinal biopsies were performed in children suffering from coeliac and other diseases and were stained by the 'astra-blau' method for visualising granulated mast cells. The density of granulated mast cells (per microscopical field) in treated coeliac disease and in 3 control groups (patients suffering from milk allergy, failure to thrive, or protracted diarrhoea) was 15-18 cells per microscopical field, which contrasted with a mean of 6.8 cells in untreated coeliac disease. It is concluded that exposure to gluten in coeliac disease results in degranulation of mast cells, while exposure to milk in milk allergy has no such effect.

The mast cell is of mesenchymal origin. It appears to be essential for the growth and repair of tissues, and it participates in inflammatory and immunological reactions. The distribution of these cells in the body varies from organ to organ. In the intestine the mast cell can be found in the villi, around the glands of Lieberkühn, and within the submucosa of the small intestine and caecum. ${ }^{1}$ The shape, number, and function of mast cells vary according to their site along the gastrointestinal tract. ${ }^{2}$ During fetal development, infancy, and childhood there is a steady increase in intestinal mast cells; with advancing age their numbers tend to decrease. ${ }^{3}$ Intestinal mast cells in the rat differ from mast cells in other parts of the body, both histochemically and morphologically. ${ }^{4-5}$ Intestinal mast cells in disease have received little attention. In Crohn's disease there appears to be a pronounced reduction of these cells in the affected tissue, while in ulcerative colitis colonic mast cells are increased. ${ }^{6}$ In children with milk-protein allergy, an increase in IgE-bearing plasma cells has been described after milk challenge, while at the same time, degranulating mast cells can be discerned by electron microscopical examination. ${ }^{7}$ The purpose of this study was to investigate the numbers of mast cells in the intestine of children with coeliac disease and other diseases.

\section{Patients and methods}

Group 1. Patients with coeliac disease. Of our series of patients with coeliac disease we chose blocks of biopsy sections obtained from 1973 onwards. There were 25 blocks that were suitable for staining for mast cells. The ages of the children at biopsy varied from 6 months to 4 years. The diagnosis of the patients depended on a detailed case history and investigation, failure to gain (or loss of) weight, intestinal biopsy, and response to a gluten-free diet.

Group 2. This comprised 3 subgroups: (2a) 35 children with mild protracted diarrhoea, of normal weights, and with jejunal biopsies that did not suggest coeliac disease. (2b) 19 children suffering from failure to thrive in whom biopsies ruled out the diagnosis of coeliac disease. (2c) 7 children suffering from milk allergy, diagnosed on clinical grounds according to the criteria given by Goldman et al. ${ }^{8}$ the biopsy being taken while the child was on an allergen-containing diet.

Group 3a and 3b. Children in groups $2 \mathrm{a}, \mathrm{b}$, and c, were also subdivided according to histological criteria. Group $3 a(n=36)$ had a completely normal intestinal histology; while $3 \mathrm{~b}(\mathrm{n}=25)$ had nonspecific, mild, histological changes-such as blunting of the villi and mild inflammatory exudate.

10 children who had been diagnosed as suffering from coeliac disease by the above criteria at least 18 months previously were rebiopsied while on a gluten-free diet. They were then placed on a glutencontaining diet and a further biopsy was taken 3 months later.

Intestinal biopsy was performed with a standard infant size 2-port Crosby-Kugler biopsy capsule (Quinton Instrument Co., Seattle, Washington). After removal, the biopsy specimen was placed on mesh and fixed in Bouin's fluid. Sections of $5 \mu \mathrm{m}$ 
thickness were stained with 'astra-blau'. ${ }^{9}$ Mast cells were counted using a light microscope and a $10 \times 10$ enlargement. Five microscopical fields were chosen at random. Only those mast cells that were in the vicinity of the muscularis mucosa were counted. ${ }^{10}$

\section{Results}

Table 1 shows that the age ranges in coeliac patients and controls were similar, thus eliminating variation in numbers of mast cells due to the age of the patients. The mean numbers of mast cells in groups $2 \mathrm{a}, \mathrm{b}$, and $\mathrm{c}$ ranged from 15 to 18 cells per microscopical field (Table 2). As there was no significant difference between them, they were therefore combined in one group and compared with the children suffering from coeliac disease. Group 3a with normal intestinal histology and group $3 \mathrm{~b}$, with nonspecific morphological changes had an equal mast cell content (Table 3). Table 2 and Fig. 1 show that children suffering from coeliac disease (group 1) had less than half the number of mast cells compared with children in group 2 . Using the $t$ test the differenr? was highly significant $(\mathrm{P}<0 \cdot 001)$.

Table 1 Percentage of individuals in each age group

\begin{tabular}{lll}
\hline Age (months) & $\begin{array}{l}\text { Coeliacs } \\
(n=25)\end{array}$ & $\begin{array}{l}\text { Controls } \\
(n=61)\end{array}$ \\
\hline$<6$ & 0 & 4 \\
$6-9 \cdot 5$ & 16 & 20 \\
$10-12 \cdot 5$ & 36 \\
$13-18$ & $12\}^{4}$ & 18 \\
$19-24$ & 12 & 22 \\
$25-26$ & 8 & 10 \\
$>36$ & 12 & 6 \\
\hline
\end{tabular}

Table 2 Mean numbers of mast cells per microscopical field

\begin{tabular}{lcc}
\hline Group & $\begin{array}{l}\text { Mean numbers of } \\
\text { mast cells/field }\end{array}$ & $S D$ \\
\hline 1 (coeliac disease), $\mathrm{n}=25$ & $6 \cdot 8$ & $3 \cdot 85$ \\
2a (protracted diarrhoea), $\mathrm{n}=35$ & $18 \cdot 0$ & $5 \cdot 60$ \\
2b (failure to thrive), $\mathrm{n}=19$ & $15 \cdot 0$ & $4 \cdot 75$ \\
2c (milk allergy), $\mathrm{n}=7$ & $17 \cdot 6$ & $6 \cdot 38$ \\
\hline
\end{tabular}

Table 3 Mean numbers of mast cells per microscopical field

\begin{tabular}{lll}
\hline Group & $\begin{array}{l}\text { Mean numbers of } \\
\text { mast cells/field }\end{array}$ & $S D$ \\
\hline $3 a(n=36)$ & $17 \cdot 3$ & $5 \cdot 33$ \\
$3 b(n=25)$ & $16 \cdot 5$ & $5 \cdot 75$ \\
\hline
\end{tabular}

Groups $3 a$ and $3 b$ relate to the same patients as groups $2 a, b$, and $c$. In this table the patients are divided according to their histological criteria, group $3 a$ being those with normal histology and group $3 b$ those with nonspecific intestinal disease.
Children with treated coeliac disease had numbers of mast cells equal to those of the control groups. Three months after the introduction of a giutencontaining diet the numbers of granulated mast cells decreased in 9 of the 10 children in this group (Figs 2 and 3).

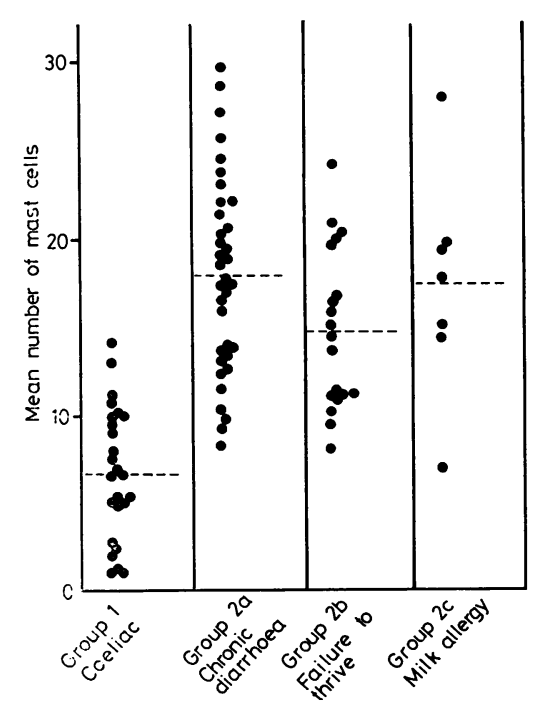

Fig. 1 Total and mean number of granulated mast cells per microscopical field in the groups.

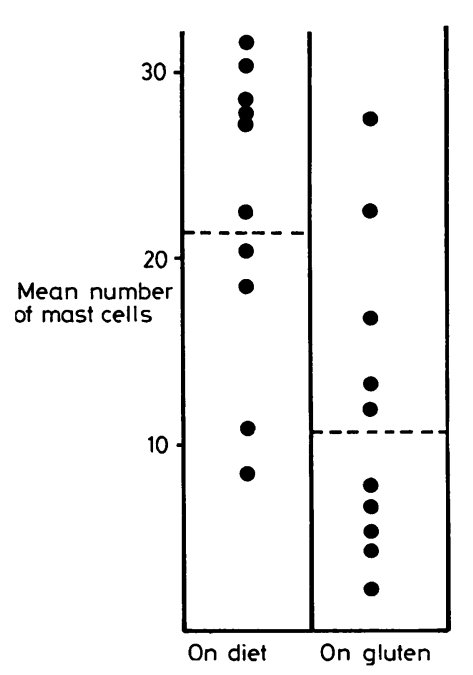

Fig. 2 Mean numbers of granulated mast cells per microscopical field in treated and untreated coeliac disease. 


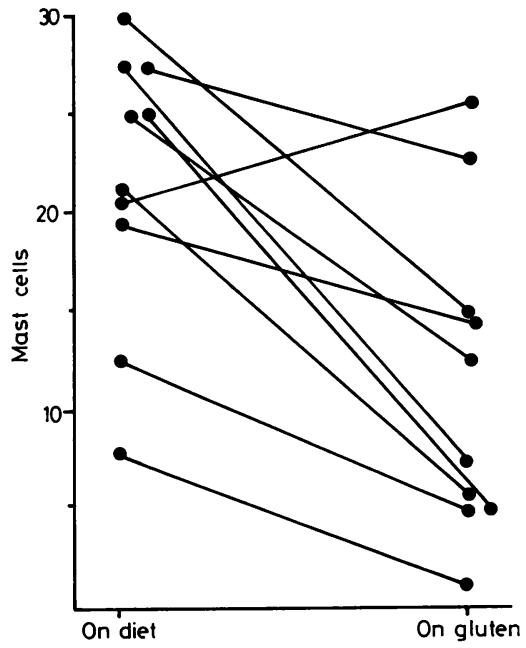

Fig. 3 Change in numbers of granulated mast cells in duodenal biopsy in 10 patients while on gluten-free diet and after receiving gluten for 3 months.

\section{Discussion}

As the density of mast cells in the intestine is a function of the age of the individual ${ }^{3}$ we took care that the ages of our coeliac patients were comparable with those of the control group. The control group comprised patients suffering from a number of conditions warranting intestinal biopsy, and included children with protracted diarrhoea without failure to thrive, most of whom could be classified as having suffered from the irritable bowel syndrome. Group $2 \mathrm{~b}$ had no demonstrable gastrointestinal disease; their intestinal biopsies were taken as part of our routine for children whose weights are $<3$ rd centile without obvious cause. Group 2c were children who were subsequently shown to be suffering from milk allergy. The biopsy was taken on admission, while the patient was still symptomatic and on allergencontaining feeds. As all the noncoeliac patients had a comparable number of mast cells, they were considered to constitute a valid control group. Furthermore, no difference in mast cell density could be found in noncoeliac patients with normal intestinal histology compared with those with nonspecific inflammatory changes.

The mast cell density in patients with active coeliac disease was less than half the density of 15-18 cells per microscopical field in the controls. Our counts were not an artefact of the altered intestinal histology of coeliac disease, as we were careful not to count mast cells in villi, but only those near the muscularis mucosa, so that in all groups investigated the whole of the microscopical field was occupied by tissue.

Our method of staining detects only granulated mast cells, so the changes which we have described refer only to granulated mast cells; we do not know what was the true number of mast cells. It must be remembered that degranulation does not destroy mast cells and these cells can regranulate in the course of time.

Mast cells contain humoral mediators which participate in inflammatory and immunological reactions. These mediators include histamine, heparin, serotonin, and other anaphylactogenic substances. ${ }^{11}$ Degranulation which leads to the release of these mediators can occur in one of two ways: (1) Nonspecific damage-for example, trauma. (2) Specific damage-drugs, chemicals, allergens. ${ }^{12}$

Studies of isolated mast cell granules have provided considerable information about the molecular basis of binding and release of amines from the granules. ${ }^{13}$ Immunoglobulin $\mathrm{E}$ attaches to the cell wall of mast cells. If this immunoglobulin is specific and comes into contact with the appropriate allergen, a series of enzymatic steps ensues which culminates in degranulation and release of the mediators. ${ }^{14}$ The basophil, which is the counterpart in peripheral blood of the tissue mast cell, has been studied in patients with asthma. The number of basophils is generally increased before the attack, and decreased during the attack. In the respiratory tract, an attack of asthma is accompanied by degranulation of mast cells. ${ }^{15}$

In view of these properties of mast cells, it is surprising that we could detect no reduced density of granulated mast cells in patients with milk allergy. This finding agrees however, with a previous study in which we subjected 6 children with milk allergy to intestinal biopsies 8-12 hours after acute challenge with the allergen. Electron microscopical examination of the mucosa could not detect any degranulation of mast cells (D Lagunoff, S Freier, 1975, unpublished data.)

Children with coeliac disease on a gluten-free diet for at least 18 months and with normal intestinal histology have a normal density of granulated mast cells. The reduced density of granulated mast cells in untreated coeliac disease is therefore the result of exposure to gluten and is not the cause of the disease. This reduction in the granulated mast cell density can be detected 3 months after gluten challenge; perhaps it can be detected much earlier, but in this study 3 months was the shortest period between the start of exposure to gluten and rebiopsy. The mechanism leading to degranulation of mast cells in our patients will probably only be understood when the nature of coeliac disease has been more fully studied. For the 
moment, we can offer no more than a general statement that mast cells are known to participate in the inflammatory response as well as in tissue repair, both of which are probably present in untreated coeliac disease.

We thank the staff of the Photographic Department, Shaare Zedek Hospital, for assistance.

This work was supported by a grant from the Joint Research Fund of the Hebrew University, and Hadassah and the Archibald $\mathbf{S}$ and Leah Richer Medical Research Fund.

\section{Refcrences}

1 Samter M, ed. Immunological disease. 2nd ed. Boston: Little, Brown, 1971:381-7.

2 Kraft S C, Kirsner J B. Mast cells and the gastrointestinal tract. Gastroenterology 1960; $39: 764-70$.

3 Lindholm S. Mast cells in the wall of the alimentary canal. Acta Pathol Microbiol Scand (Suppl) 1959; Supplement 132,46-9.

4 Enerbäck L. Mast cells in rat gastrointestinal mucosa. I. Effects of fixation. Acta Pathol Microbiol Scand 1966; 66: 289-302.

5 Enerbäck L. Mast cells in rat gastrointestinal mucosa. II. Dye-binding and metachromatic properties. Acta Pathol Microbiol Scand 1966; 66: 303-12.
6 Lloyd G, Green F H Y, Fox H, Mani V, Turnberg L A. Mast cells and immunoglobulin $\mathrm{E}$ in inflammatory bowel disease. Gut 1975; 16: 861-6.

7 Shiner M, Ballard J, Smith M E. The small intestinal mucosa in cows' milk allergy. Lancet 1975 ; ii : 136-40.

8 Goldman A S, Anderson D W, Jr, Sellers W A, Saperstein S, Kniker W T, Halper S R. Milk allergy. I. Oral challenge with milk and isolated milk proteins in allergic children. Pediatrics 1963; 32: 425-43.

9 Bloom G, Kelly J W. The copper phthalocyamine dye 'Astrablau' and its staining properties, especially the staining of mast cells. Histochemie 1960; 2: 48-57.

10 Enerbäck L. Mast cells in rat gastrointestinal mucosa. III. Reactivity towards compound 48/80. Acta Pathol Microbiol Scand 1966; 66: 313-22.

11 Asboe-Hansen G. Mast cells in health and disease. Bull NY Acad Med 1968; 44: 1048-55.

12 Lagunoff $D$. Contribution of electron microscopy to the study of mast cells. J Invest Dermatol 1972; 58: 296-311.

13 Goth A, Johnson A R. Current concepts on the secretory function of mast cells. Life Sci 1975; 16: 1201-13.

14 Mendoza G, Metzger $H$. Distribution and valency of receptor for IgE on rodent mast cells and related tumour cells. Nature 1976; 264: 548-50.

15 Kimura I, Moritani Y, Tanizaki Y. Basophils in bronchial asthma with reference to reagin-type allergy. Clin Allergy 1973; 3: 195-202.

Correspondence to Dr S Freier, Department of Paediatrics, Shaare Zedek Medical Centre, Bayit Vagan, Jerusalem, Israel.

Received 5 September 1979 